Determination of The Potential Use of Exopolysaccharide-Producing Streptococcus salivarus ssp. thermophilus and Lactobacillus delbrueckii ssp. bulgaricus in Yogurt

\author{
Ayşe Esin KILINÇ², Yekta GEZGINÇ⿻ ${ }^{1}$ \\ ${ }^{1}$ Kahramanmaraş Sütçü İmam Üniversitesi, Mühendislik-Mimarlık Fakültesi, Gıda Mühendisliği Ana Bilim Dalı, 46050, Kahramanmaraş, \\ ${ }^{2}$ Kahramanmaraş Sütçü İmam Üniversitesi, Fen Bilimleri Enstitüsü, Gıda Mühendisliği Ana Bilim Dalı, 46050, \\ ${ }^{1} \mathrm{https}: / /$ orcid.org/0000-0002-9358-4708, ${ }^{2} \mathrm{https}: / /$ orcid.org/0000-0002-3230-2850 \\ $\bowtie$ : yekgan@ksu.edu.tr
}

\begin{abstract}
In this study exopolysaccharide production quantities of 88 Streptococcus thermophilus and 28 Lactobacillus bulgaricus bacteria were investigated. Chemical, physical and sensory properties of yogurt in which added the combination of the highest and the lowest exopolysaccharide producing bacteria were determined. In all 9 yogurt samples titration acidity, $\mathrm{pH}$, acetaldehyde and lactate production, serum separation, viscosity and sensory evaluation results were investigated. In the yogurt samples examined, acidity in terms of lactic acid (\%), $\mathrm{pH}$, acetaldehyde, lactate, syneresis and viscosity values were found in the range of $0.63-1.055 \%, 3.82-4.46,20.45-33.63$ $\mathrm{mg} \mathrm{kg}^{-1}, 50.41-144.56 \mathrm{mg} \mathrm{kg}^{-1}$ 9.3-10.6 mL, 5339-9280 cP, respectively. Sensory properties of yogurts produced with the highest exopolysaccharide producing bacteria combination were most preferred by the panel group.
\end{abstract}

Research Article

$\begin{array}{ll}\text { Article History } & \\ \text { Received } & : 16.05 .2019 \\ \text { Accepted } & : 21.08 .2019\end{array}$

Keywords

Yogurt

Streptococcus thermophilus

Lactobacillus bulgaricus

Exopolysaccharide

\title{
Ekzopolisakkarit Üreten Streptococcus salivarus ssp. thermophilus ve Lactobacillus delbrueckii ssp. bulgaricus 'ların Yoğurtta Kullanım Potansiyelinin Belirlenmesi
}

\section{ÖZET}

Bu çalı̧̧mada 88 adet Streptococcus thermophilus ve 28 adet Lactobacillus bulgaricus bakterilerinin ekzopolisakkarit üretim miktarları araştırılmıştır. En yüksek ve en düşük ekzopolisakkarit üreten bakteri kombinasyonları kullanılmış ve elde edilen yoğurtların kimyasal, fiziksel ve duyusal özellikleri tespit edilmiştir. Üretilen 9 yoğurt örneğinde titre edilebilir asitlik, $\mathrm{pH}$, metabolit üretimi, serum ayrılması, viskozite ve duyusal değerlendirme sonuçları incelenmiştir. Yoğurt örneklerinde laktik asit cinsinden asitlik değeri, $\mathrm{pH}$, asetaldehit, laktik asit, serum ayrılması ve viskozite değerleri sirasiyla \% 0.63-1.055, 3.82-4.46, 20.45-33.63 mg kg-1, 50.41-144.56 $\mathrm{mg} \mathrm{kg}{ }^{-1}, 9.3-10.6 \mathrm{~mL}, 5339-9280 \mathrm{cP}$ değerleri arasında bulunmuştur. En yüksek ekzopolisakkarit üreten bakteri kombinasyonları ile üretilen yoğurtların duyusal özelliklerinin panelistler tarafından daha çok beğenildiği saptanmıştır.

\section{Araştırma Makalesi}

Makale Tarihçesi
Geliş Tarihi $: 16.05 .2019$

Kabul Tarihi : 21.08 .2019

\section{Anahtar Kelimeler}

St. thermophilus

Lb. bulgaricus

Yogurt

Ekzopolisakkarit

To Cite : Kılınç AE, Gezginç Y 2019. Determination of The Potential Use of Exopolysaccharide-Producing Streptococcus salivarus ssp. thermophilus and Lactobacillus delbrueckii ssp. bulgaricus in Yogurt. KSU J. Agric Nat. 22 (Suppl 2): 401-408. DOI: 10.18016/ksutarimdoga.vi.566373

\section{INTRODUCTION}

One of the most known of the fermented foods is yogurt. Yogurt is identified as a coagulated milk product that results from the fermentation of lactic acid in milk by Lactobacillus bulgaricus ( $L b$. bulgaricus) and Streptococcus thermophilus (St. thermophilus) (Bourlioux and Pochart, 1988). In milk medium lactic acid bacteria (LAB) as starter cultures exhibit symbiotic relations during their growth for yogurt production. So, well-selected mixture of LAB species is used to complete each other and to achieve a considerable efficiency in acid production (Chandan and Shahani, 1993). Yogurt starter cultures have a remarkable impact on smooth texture, relevant viscosity, acceptable flavor and low post fermentation acidity of the milk product (Cheng, 2010).

Some LAB secrete a polysaccharide polymer. This extracellular polysaccharide, or exopolysaccharide 
(EPS) is economically important because it can impart functional effects to foods and confer beneficial health effects (Welman and Maddox, 2003). In some countries, EPS plays a vital role in the production of fermented dairy products (Duboc and Mollet, 2001). EPSs from LAB have found their most precious application in the improvement of the texture, rheology and mouthfeel of fermented milk products, such as yogurt. The yogurt cultures producing EPS may reduce the extent of syneresis that considered as a major defect in yogurt (Güzel-Seydim et al., 2005).

There is a high consumer request for smooth and creamy yogurt products, which is typically met by increasing the content of fat, sugar, proteins or stabilizers. Consumer request for products with low fat or sugar content and low levels of additives, as well as cost factors, make EPSs a suitable alternative (Jolly et al., 2002). Although having no taste of their own, EPSs from LAB increase the time the milk product spends in the mouth, and hence impart an enhanced perception of taste (Duboc and Mollet, 2001). An additional hypothesized physiological benefit is that EPSs will remain for longer in the gastrointestinal tract, thus enhancing colonization by probiotic bacteria (German et al., 1999). In addition, LAB EPSs have been asserted to have antitumor effects (Kitazawa et al., 1998), immunostimulatory activity (Hosono et al., 1997 , Chabot et al., 2001) and to lower blood cholesterol (Nakajima et al., 1992).

In these days, a great importance is given to use of EPS-producing LAB in the production of fermented dairy products. Because of this importance, a study has been planned and potential use of exopolysaccharideproducing LAB in yogurt has been investigated. For this purpose, EPS production quantities of Streptococcus salivarius ssp. thermophilus and Lactobacillus delbrueckii ssp. bulgaricus strains were found and the combinations of the highest and the lowest EPS-producing bacteria were used for yogurt production. The yogurts were compared in terms of titration acidity, $\mathrm{pH}$, acetaldehyde and lactate production, serum separation, viscosity and sensory evaluation.

\section{MATERIAL and METHODS}

Bacterial strains used in this study were listed in Table 1. UHT whole milk was used for production of yogurt.

\section{Growth of Bacterial Strains}

Control strains of St. thermophilus NIZO 130 and $L b$. delbrueckii ssp. bulgaricus LB 340 LYO 2 DCU were obtained from Netherlands Institute for Dairy Research and Danisco. Isolates of St. thermophilus and Lb. delbrueckii ssp. bulgaricus were provided from Kahramanmaras Sutcu Imam University Food Engineering Laboratory $-80{ }^{\circ} \mathrm{C}$ Culture Collection. St.thermophilus strains were cultured in M17 medium added with $1 \%(\mathrm{w} / \mathrm{v})$ sucrose (SM17 medium) at $42{ }^{\circ} \mathrm{C}$ whereas $L b$. bulgaricus strains were grown on de ManRogosa and Sharpe broth (MRS) at $37^{\circ} \mathrm{C}$.

Table 1. Bacterial strains and combinations used for yogurt production

\begin{tabular}{|l|l|}
\hline Strains & Combinations \\
\hline BioStr 33 & BioStr 33-BioLb 94 \\
\hline BioStr 56 & BioStr 33-BioLb 103 \\
\hline BioStr 164 & BioStr 56-BioLb 94 \\
\hline BioStr 166 & BioStr 56-BioLb 103 \\
\hline BioStr 132 & BioStr 164-BioLb 94 \\
\hline NIZO130 (control) & BioStr 164-BioLb 103 \\
\hline BioLb 94 & BioStr 166-BioLb 94 \\
\hline BioLb 103 & BioStr 166-BioLb 103 \\
\hline BioLb 124 & BioStr 132-BioLb 124 \\
\hline $\begin{array}{l}\text { LB 340 LYO 2 DCU } \\
\text { (control) }\end{array}$ & $\begin{array}{l}\text { NIZO130-LB 340 LYO 2 DCU } \\
\text { (control) }\end{array}$ \\
\hline
\end{tabular}

\section{Exopolysaccharide Isolation and Quantification}

Valerie et al. (1999)'s method was used for determination of EPS production quantities of $S t$. thermophilus and Lb. bulgaricus strains. At the end of the incubation, the samples were cooled to $4{ }^{\circ} \mathrm{C} .1 \mathrm{~mL}$ of the sample was centrifuged at $13000 \mathrm{rpm}$ for $25 \mathrm{~min}$ by adding $85 \%$ trichloroacetic acid (TCA) $(0.17 \%=1.7$ $\mu \mathrm{L})$. In order to determine EPS production quantities, Dubois et al. (1956) 's method was used. Total EPS production quantities were determined by spectrophotometric method by applying phenol sulfuric acid method using standard glucose. The optical density was measured spectrophotometrically at $490 \mathrm{~nm}$. EPS quantities of samples were determined as $\mathrm{mg} \mathrm{L}^{-1}$.

\section{Yogurt Production}

UHT milk was used for yogurt production. After the milk was heated to $45{ }^{\circ} \mathrm{C}$ in a water bath, it was distributed to a sterilized glass bottle $(200 \mathrm{~mL})$ under aseptic conditions. Lb. delbrueckii ssp. bulgaricus and $S t$. thermophilus starters were inoculated with $1 \%$ (v/v). The starter cultures that contain NIZO130 and LB 340 LYO 2 DCU, were used as the control group. One of the $S t$. thermophilus isolates was mixed with one of the $L b$. delbrueckii ssp. bulgaricus isolates and, thus 10 different mixed starter sets were generated. Each mixed inoculation was adequate to obtain initial

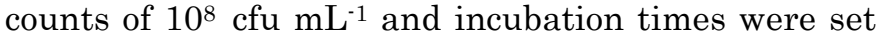
for $6 \mathrm{~h}$ to find better combination. Fermented products were cooled at $4-5{ }^{\circ} \mathrm{C}$ overnight before testing at different periods of time. Bacterial strains were selected from the highest EPS-producing (BioStr 33, BioStr 56, BioStr 164, BioStr 166, BioLb 94 and BioLb 103) and the lowest EPS-producing (BioStr 132 ve BioLb 124) strains respectively and control strains. Bacterial strains and combinations used for yogurt production are listed in Table 1. 


\section{Chemical Analysis of Yogurt}

Titration acidity determination was followed by Dave and Shah (1997) and Metin and Öztürk (2002) methods; $10 \mathrm{~g}$ of the homogenous sample was weighed and $10 \mathrm{~mL}$ of distilled water at $40{ }^{\circ} \mathrm{C}$ was added. 0.5 $\mathrm{mL}$ of phenolphthalein indicator solution was added dropwise to the homogenized diluted yogurt and titrated with a $0.1 \mathrm{~N} \mathrm{NaOH}$ solution until at least 30 sec. permanent pink color was obtained. The $\mathrm{pH}$ values of the yogurt samples were measured by using a microprocessor $\mathrm{pH}$ meter (Inolab WTW, Measurement system, FL, ABD).

The amounts of lactate and acetaldehyde produced in yogurt samples were analyzed using HPLC (Özoğul et al., 2000). Briefly, $1 \mathrm{~mL}$ of a yogurt sample was centrifuged at $14.000 \mathrm{~g}$ at $4{ }^{\circ} \mathrm{C}$ for $5 \mathrm{~min}$. The supernatant was filtered and placed in a fresh ependorf tube. The sample was diluted 1 fold in $0.5 \%$ meta-phosphoric acid (Sigma-Aldrich, MO, USA) and $20 \mu \mathrm{L}$ of the solution was injected onto the HPLC. Separation was made on a Capcell Pak $5 \mu \mathrm{M}$ C18 MG column $(150 \times 4.6 \mathrm{~mm})$.

\section{Physical Analysis of Yogurt}

The viscosity of the yoghurt samples was measured at $4{ }^{\circ} \mathrm{C}$ by a Brookfield viscometer, Model DV-III Ultra (Brookfield Engineering Laboratories, Stoughton, MA, USA) with an RV spindle (spindle No. 63) set at 10 rpm. All measurements were taken in triplicates and readings (cP) were taken for each sample at $30 \mathrm{~s}$ (Gassem and Frak, 1991). Syneresis was measured by weighing $100 \mathrm{~g}$ yoghurt in to a stainless-steel cylinder (50 mm ID) with a 120 mesh stainless steel screen base. The amount of whey $(\mathrm{mL})$ collected after $3 \mathrm{~h}$ at 4 ${ }^{\circ} \mathrm{C}$ was taken as an index of syneresis (Modler et al., 1983).

\section{Sensory Analysis of Yogurt}

12 panelists were used in the sensory evaluation of the yogurt samples. Samples were presented to panelists and evaluated according to the taste, smell, consistency, and appearance criteria over 5 points.

\section{Statistical Analysis}

The Shaphiro wilk test was used to check the normal distribution of continuous variables. Mann Whitney u test was used to compare 2 independent groups of nonnormal distributions. Introductory statistics were given as mean \pm SD values. SPSS for Windows version 23.0 package program was used for statistical analysis and $\mathrm{P}<0.05$ was considered statistically significant.

\section{RESULTS and DISCUSSION}

Chemical Properties of Yogurt Samples

The EPS production of the 88 St. thermophilus and 28 $L b$. bulgaricus strains isolated from traditional yogurt were analysed. In Figure 1 and 2, it showed that different strains had different EPS production. In this study the highest EPS production amounts were obtained from BioStr 56 (408.74 $\left.\pm 3.17 \mathrm{mg} \mathrm{L}^{-1}\right)$, BioStr $166\left(370.21 \pm 0.20 \mathrm{mg} \mathrm{L}^{-1}\right)$, BioStr $33(365.75 \pm 8.08 \mathrm{mg}$ $\mathrm{L}^{1}$, BioStr $164\left(337.67 \pm 5.76 \mathrm{mg} \mathrm{L}^{-1}\right)$ and BioLb 94 (332.35 $\left.\pm 2.89 \mathrm{mg} \mathrm{L}^{-1}\right)$, BioLb $155\left(242.83 \pm 9.63 \mathrm{mg} \mathrm{L}^{-1}\right)$, BioLb $159 \quad\left(214.86 \pm 13.22 \quad \mathrm{mg} \quad \mathrm{L}^{-1}\right), \quad$ BioLb 103 $\left(213.01 \pm 3.29 \mathrm{mg} \mathrm{L}^{-1}\right)$ strains and the lowest EPS production amounts were obtained from BioStr 132 (38.15 $\left.\pm 8.02 \mathrm{mg} \mathrm{L}^{-1}\right)$ and BioLb $124\left(54.72 \pm 11.71 \mathrm{mg} \mathrm{L}^{-}\right.$ 1) strains. Han et al. (2016) reported the EPS production of St. thermophilus strains range from $45 \pm 7$ $\mathrm{mg} \mathrm{L}^{-1}$ to $384 \pm 22 \mathrm{mg} \mathrm{L}^{-1}$. Garcia-Garibay and Marshall (1991) were determined for Lb. bulgaricus strains between $60 \mathrm{mg} \mathrm{L}^{-1}$ and $150 \mathrm{mg} \mathrm{L}^{-1}$.

Acidification capacity of a strain is the priority characteristic to select it as a yogurt starter culture. Acidity is responsible of aroma, texture and flavor of yogurt. When the acidity levels of the samples were examined, it was observed that the acidity levels of the samples produced with the high amount EPSproducing strains were higher than the samples produced with the low amount EPS-producing strains. The acidity (\%) values of the yogurt samples produced using the highest and lowest EPS producing strains and control strains are given in Table 2. The highest acidity value was found in the yogurt produced with Str164-Lb94 combination (1.05 $\pm 0.02 \%)$ and the lowest acidity value was found in the yogurt produced with Str132-Lb124 combination $(0.63 \pm 0.00 \%)$. The acidity value in the yogurt produced by the control culture was $0.91 \pm 0.02 \%$. In the statistical analyzes, it was determined that the effect of all strains on acidity was significant $(\mathrm{p}<0.05)$. The titratable acidity $(\%)$ values of the obtained yogurt samples were between $0.63 \pm$ $0.00 \%-1.05 \pm 0.02 \%$. According to Turkish Standards Institution method (Anonymus, 1999), it is stated that the degree of acidity that should be in yogurt should not be less than $0.8 \%$ and not more than $1.6 \%$ by mass of lactic acid type. Güzel-Seydim et al. (2005) reported the degree of acidity between $0.7 \%$ and $0.78 \%$. The $\mathrm{pH}$ values of the yogurt samples produced using the highest and lowest EPS producing strains and control strains are given in Table 2 . The highest $\mathrm{pH}$ value was found in the yogurt produced by the combination of Str132-Lb124 (4.46 \pm 0.03$)$ and the lowest $\mathrm{pH}$ value was found in the yogurt produced by the combination of Str164-Lb94 (3.82 \pm 0.05$)$. The $\mathrm{pH}$ value of the yogurt produced by the control culture was $4.20 \pm 0.02$. When the $\mathrm{pH}$ values of the samples were examined, it was found that the $\mathrm{pH}$ values of the samples produced with the highest number of EPS-producing strains were lower than the samples produced with the lowest number of EPS-producing strains. In the statistical analyzes, it was determined that the effect of all strains on $\mathrm{pH}$ was significant $(\mathrm{p}<0.05)$. 
EPS production of St.thermophilus strains

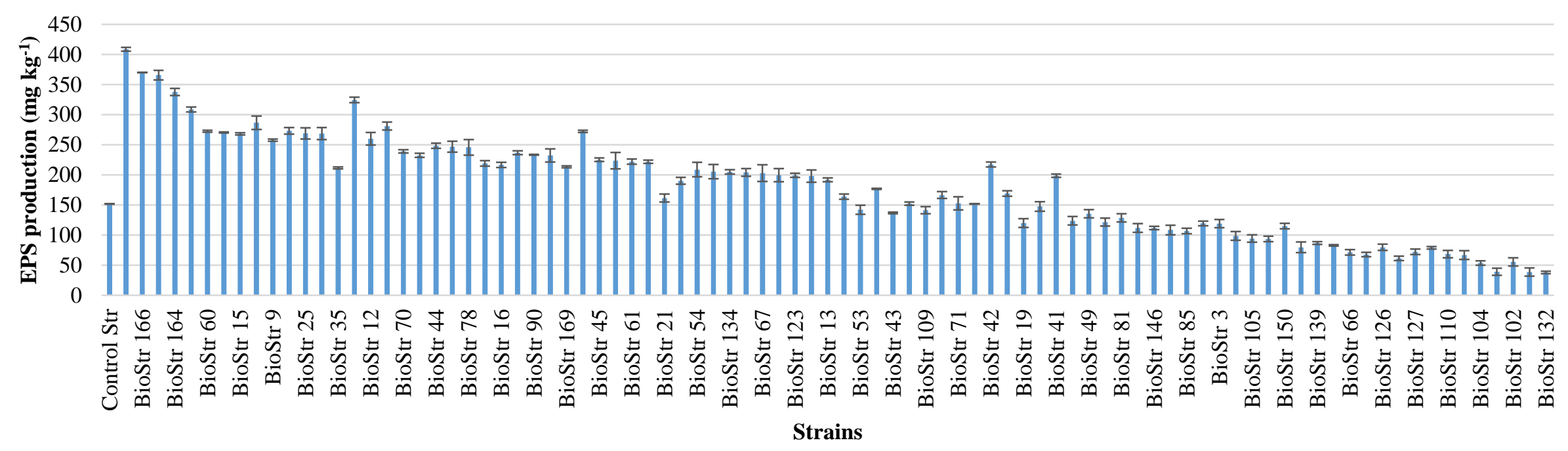

Figure 1. EPS production of St.thermophilus strains 


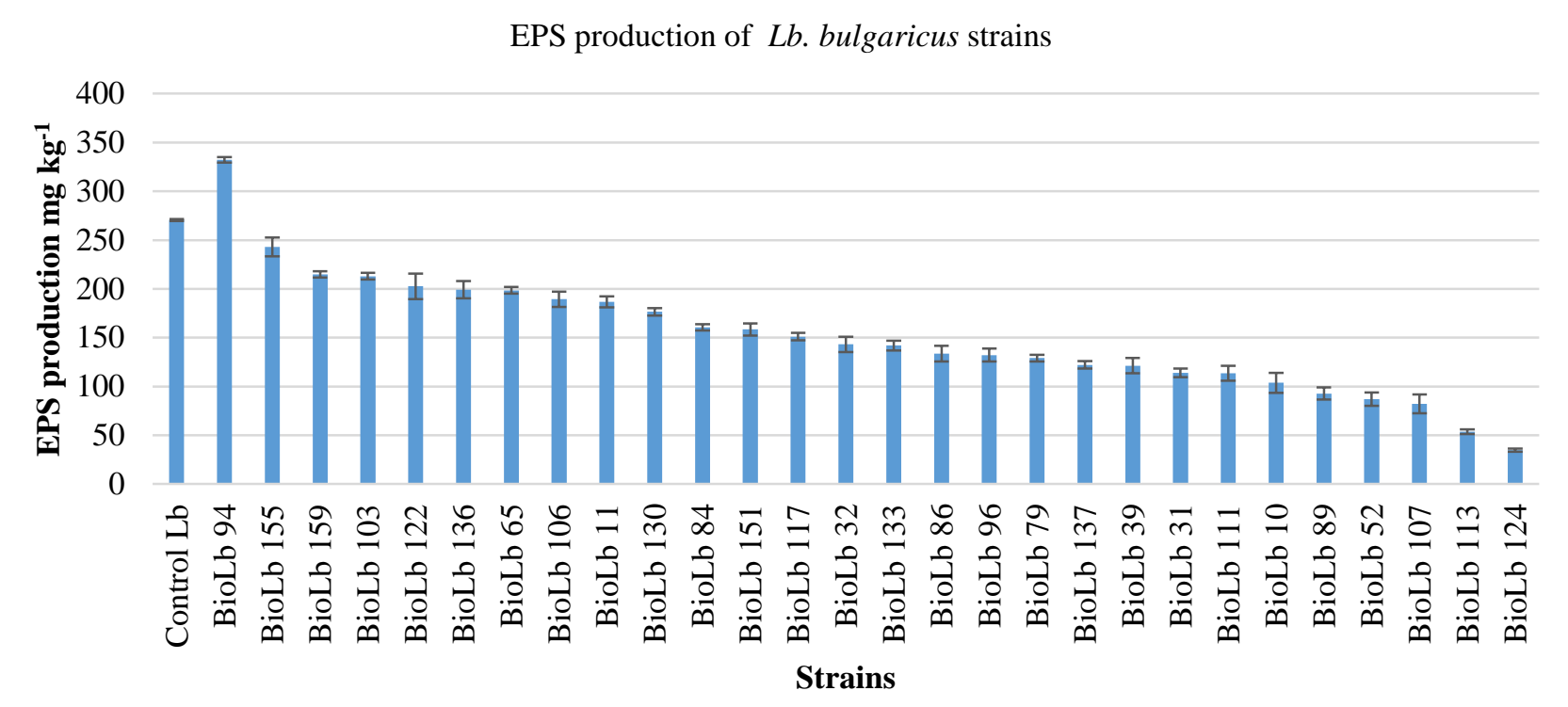

Figure 2. EPS production of Lb. bulgaricus strains

Table 2 . Acidity (\%) and $\mathrm{pH}$ values of yogurts produced with different combinations*

\begin{tabular}{|c|c|c|}
\hline Strain combinations & Acidity (\%) & $\mathrm{pH}$ \\
\hline Str 33-Lb94 & $0.72 \pm 0.01^{\mathrm{c}}$ & $4.34 \pm 0.02^{\mathrm{bc}}$ \\
\hline Str33-Lb103 & $0.69 \pm 0.05^{\mathrm{cd}}$ & $4.38 \pm 0.02^{\mathrm{abc}}$ \\
\hline Str56-Lb94 & $0.88 \pm 0.03^{\mathrm{b}}$ & $3.89 \pm 0.02^{\mathrm{ef}}$ \\
\hline Str56-Lb103 & $0.65 \pm 0.01^{\mathrm{d}}$ & $4.41 \pm 0.00^{\mathrm{ab}}$ \\
\hline Str164-Lb94 & $1.05 \pm 0.02^{\mathrm{a}}$ & $3.82 \pm 0.05^{\mathrm{f}}$ \\
\hline Str164-Lb103 & $0.66 \pm 0.01^{\text {cd }}$ & $4.33 \pm 0.01^{\mathrm{bc}}$ \\
\hline Str166-Lb94 & $0.99 \pm 0.06^{\mathrm{a}}$ & $3.92 \pm 0.02^{\mathrm{e}}$ \\
\hline Str166-Lb103 & $0.67 \pm 0.01^{\mathrm{cd}}$ & $4.30 \pm 0.06^{\mathrm{c}}$ \\
\hline Str132-Lb124 & $0.63 \pm 0.00^{\mathrm{d}}$ & $4.46 \pm 0.03^{\mathrm{a}}$ \\
\hline Control & $0.91 \pm 0.02^{\mathrm{b}}$ & $4.20 \pm 0.02^{\mathrm{d}}$ \\
\hline
\end{tabular}

*Different letters within each column are significant at $P<0.05$

The $\mathrm{pH}$ values of the obtained yogurt samples were between 3.82 $\pm 0.05-4.46 \pm 0.03$. Measurement of $\mathrm{pH}$ presents a critical quality control step in the production of yogurt. Yogurt samples obtained with high amounts of EPS-producing bacterial combinations have low $\mathrm{pH}$ values from yogurt sample obtained with low amount of EPS-producing bacteria combination. The $\mathrm{pH}$ changes in commercial yogurt samples in western countries range between 3.8 and 4.0 (Birollo et al., 2000). The $\mathrm{pH}$ values varied within the range are generally considered as "acceptable" for yogurt. However, in Turkey, most consumers find yogurts with the $\mathrm{pH}$ between 4.8 to 5.2 more desirable (Dede et al., 2004). Furthermore, different commercial brands may have been produced by different starter cultures, which may have different acidification properties.

The acetaldehyde and lactic acid (lactate) values of yogurt samples produced using the highest and lowest EPS producing strains and control strains are given in Table 3. The acetaldehyde values of the obtained yogurt samples were between $20.45 \pm 0.50 \mathrm{mg} \mathrm{kg}^{-1}$ $33.63 \pm 0.69 \mathrm{mg} \mathrm{kg}^{-1}$. The basic aroma substance for the characteristic yogurt flavor is acetaldehyde. The highest acetaldehyde values were found in the yogurts produced with the combinations of Str33-Lb94 and Str56-Lb94 (33.63 $\pm 0.69 \mathrm{mg} \mathrm{kg}^{-1}, 33.22 \pm 1.30 \mathrm{mg} \mathrm{kg}^{-1}$ ) and the lowest acetaldehyde value was found in the yogurt produced with the combination of Str132-Lb124 $\left(20.45 \pm 0.50 \mathrm{mg} \mathrm{kg}^{-1}\right)$. The acetaldehyde level in the yogurt produced by the control was $25.33 \pm 0.42 \mathrm{mg} \mathrm{kg}$ 1. In the statistical analyzes, it was determined that the effect of all strains on acetaldehyde level was significant $(p<0,05)$. Acetaldehyde, the component that is responsible of fresh, fruity, pungent taste of yogurt, is produced by starter cultures from lactose and/or due to the formation of acetyl coenzyme A (Chaves et al., 2002). It has been accepted that the amount of acetaldehyde should be among 23 and $40 \mathrm{mg} \mathrm{kg}^{-1}$ of yogurt for a desirable aroma (Cheng, 2010). In fact, the values were generally lower than expected for a mixed starter culture ( 2.0 and $\left.41.0 \mathrm{mg} \mathrm{kg}^{-1}\right)$ even on the first day of the storage (Routray and Mishra, 2011). 
Table 3. Lactate and Acetaldehyde values of yogurts produced with different combinations $\left(\mathrm{mg} \mathrm{kg}^{-1}\right)^{*}$

\begin{tabular}{|l|l|l|}
\hline $\begin{array}{l}\text { Strain } \\
\text { combinations }\end{array}$ & \multicolumn{1}{|c|}{$\begin{array}{c}\text { Lactate } \\
\left(\mathrm{mg} \mathrm{kg}^{-1}\right)\end{array}$} & $\begin{array}{c}\text { Acetaldehyde } \\
\left(\mathrm{mg} \mathrm{kg}^{-1}\right)\end{array}$ \\
\hline Str 33-Lb94 & $127.64 \pm 0.82^{\mathrm{b}}$ & $33.63 \pm 0.69^{\mathrm{a}}$ \\
\hline Str33-Lb103 & $144.56 \pm 5.62^{\mathrm{a}}$ & $23.61 \pm 1.28^{\mathrm{bc}}$ \\
\hline Str56-Lb94 & $126.88 \pm 4.26^{\mathrm{b}}$ & $33.22 \pm 1.30^{\mathrm{a}}$ \\
\hline Str56-Lb103 & $65.40 \pm 5.40^{\text {def }}$ & $21.09 \pm 1.00^{\mathrm{e}}$ \\
\hline Str164-Lb94 & $60.66 \pm 4.32^{\text {ef }}$ & $22.19 \pm 0.72^{\mathrm{de}}$ \\
\hline Str164-Lb103 & $78.45 \pm 7.55^{\mathrm{bc}}$ & $23.89 \pm 0.56^{\mathrm{bc}}$ \\
\hline Str166-Lb94 & $80.14 \pm 6.21^{\mathrm{bc}}$ & $20.96 \pm 0.64^{\mathrm{e}}$ \\
\hline Str166-Lb103 & $71.11 \pm 5.04^{\mathrm{de}}$ & $29.08 \pm 0.83^{\mathrm{b}}$ \\
\hline Str132-Lb124 & $50.41 \pm 4.31^{\mathrm{f}}$ & $20.45 \pm 0.50^{\mathrm{e}}$ \\
\hline Control & $90.44 \pm 7.42^{\mathrm{c}}$ & $25.33 \pm 0.42^{\mathrm{c}}$ \\
\hline
\end{tabular}

*Different letters within each column are significant at $P<0.05$

Lactate, which is extremely important in the yogurt aroma, allows the yogurt to acquire acidic, sharp, pleasing taste. During fermentation of milk into yogurt, pyruvate is produced from glucose through Embden-Meyerhoff Pathway (EMP) and it is transformed to lactic acid by lactate dehydrogenase enzyme (Yildiz, 2010). Lactic acid production plays a specific role in the aroma and flavor properties of yogurt. The primary function of lactic acid cultures used in yogurt manufacture is to produce lactic acid required for the formation of the coagulum. Around 20$40 \%$ of lactose present in milk is converted into lactic acid during yogurt fermentation process and the content of lactic acid in yogurt reaches up to $0.9 \%$ (Tamime and Robinson, 2007).

The combinations of the strains were found to produce different amounts of lactic acid and these differences were statistically significant $(\mathrm{P}<0.05)$ compared to the control. Analyses made for each yogurt sample revealed that the maximum amount of lactic acid was generated by Str33-Lb103 combination (144.56 \pm 6.62 $\mathrm{mg} \mathrm{kg}-1$ ), while the minimum accumulation value was measured in Str132-Lb124 (50.41 $\left.\pm 4.31 \mathrm{mg} \mathrm{kg}^{-1}\right)$ at the initiation. Lactic acid contents of the samples in control group, on the other hand, were determined to $90.44 \pm 7.42 \mathrm{mg} \mathrm{kg}^{-1}$ (Table 3). Although lactic acid producing capacity is one of the most important factors to be evaluated for a starter culture to be used in a well-flavored yogurt production, it is also known that not only the amount but also the ratio of $\mathrm{D}(-) / \mathrm{L}(+)$ isomers are needed to be considered in order to make a reasonable judgement about its contribution to the taste (Gezginc et al, 2015). Knowing that we did not perform such a separation in terms of lactic acid isomers, it is not feasible for us to make a conclusion on this regard.

\section{Physical Properties of Yogurt Samples}

Syneresis is an important factor effecting the acceptance of yogurts by consumers. Syneresis is obtained by measuring the quantity of liquid separated from yogurt as a function of time. Syneresis values of the yogurt samples produced using the highest and lowest EPS producing strains and control strains are given in Table 4 . The highest serum separation value was found in the yogurt produced with Str132-Lb124 combination $(10.6 \pm 0.2 \mathrm{~mL})$ and the lowest serum separation value was found in the yogurt produced with Str33-Lb94 combination $(9.3 \pm 0.1 \mathrm{~mL})$. Syneresis value in yogurt produced with control culture was found $10.25 \pm 0.14 \mathrm{~mL}$. When the syneresis values of the samples were examined, it was found that the syneresis values of the samples produced with the highest amounts of EPS-producing strains were lower than the samples produced with the lowest amount of EPS-producing strains. In the statistical analyzes, it was determined that the effect of all strains on syneresis value was significant $(\mathrm{p}<0.05)$.

The syneresis values of the obtained yogurt samples were between $9.30 \pm 0.10 \mathrm{~mL}-10.60 \pm 0.20 \mathrm{~mL}$. Syneresis or otherwise, water release is a common flaw in yogurt and an important quality criterion. Yogurt samples obtained with high amounts of EPS-producing bacterial combinations have low syneresis values from yogurt sample obtained with low amount of EPSproducing bacteria combination. Amatayakul et al., 2005, reported that yogurt samples obtained with EPSproducing bacterial combinations have low syneresis values from yogurt sample obtained with non EPSproducing bacteria combination.

Table 4. Syneresis (mL) and viscosity (cP) values of yogurts produced with different combinations *

\begin{tabular}{|l|l|l|}
\hline $\begin{array}{l}\text { Strain } \\
\text { combinations }\end{array}$ & Syneresis $(\mathrm{mL})$ & Viscosity $(\mathrm{cP})$ \\
\hline Str 33-Lb94 & $9.30 \pm 0.10^{\mathrm{c}}$ & $9280 \pm 350^{\mathrm{a}}$ \\
\hline Str33-Lb103 & $9.75 \pm 0.05^{\mathrm{b}}$ & $7485 \pm 405^{\mathrm{bc}}$ \\
\hline Str56-Lb94 & $9.75 \pm 0.15^{\mathrm{b}}$ & $8350 \pm 250^{\mathrm{a}}$ \\
\hline Str56-Lb103 & $9.40 \pm 0.10^{\mathrm{bc}}$ & $8411 \pm 409^{\mathrm{ab}}$ \\
\hline Str164-Lb94 & $9.40 \pm 0.20^{\mathrm{bc}}$ & $8770 \pm 530^{\mathrm{ab}}$ \\
\hline Str164-Lb103 & $9.35 \pm 0.15^{\mathrm{bc}}$ & $8727 \pm 476^{\mathrm{ab}}$ \\
\hline Str166-Lb94 & $9.65 \pm 0.15^{\mathrm{bc}}$ & $7585 \pm 150^{\mathrm{b}}$ \\
\hline Str166-Lb103 & $9.70 \pm 0.10^{\mathrm{bc}}$ & $8496 \pm 554^{\mathrm{ab}}$ \\
\hline Str132-Lb124 & $10.60 \pm 0.20^{\mathrm{a}}$ & $5339 \pm 132^{\mathrm{d}}$ \\
\hline Control & $10.25 \pm 0.14^{\mathrm{a}}$ & $6470 \pm 135^{\mathrm{c}}$ \\
\hline
\end{tabular}

*Different letters within each column are significant at $P<0.05$

The viscosity values of the yogurt samples produced using the highest and lowest EPS producing strains and control strains are given in Table 4. The highest viscosity value was found in the yogurt produced with the Str33-Lb94 combination $(9280 \pm 350 \mathrm{cP})$ and the lowest viscosity value was found in the yogurt produced with the Str132-Lb124 combination $(5339 \pm 132 \mathrm{cP})$. The viscosity value of the yogurt produced with the control culture was $6470.50 \pm 13.50$ 
cP. When the viscosity values of the samples were examined, it was found that the viscosity values of the samples produced with the highest amounts of EPSproducing strains were higher than the samples produced with the lowest amount of EPS-producing strains. In the statistical analyzes, it was determined that the effect of all strains on the viscosity values was significant $(\mathrm{p}<0.05)$.

The viscosity values of the obtained yogurt samples were between $5339 \pm 132 \mathrm{cP}-9280 \pm 350$ cP. Yogurt samples obtained with high amounts of EPS-producing bacterial combinations have high viscosity values from yogurt sample obtained with low amount of EPSproducing bacteria combination.

Sensory Properties of Yogurt Samples

Sensory properties of yogurt have an important effect on consumer acceptability. A good yogurt must have an unique light sour taste, a unique acidic odor. It should have a bright and homogeneous appearance, should not be in dirty color, should not be observed in serum separation. In our study, the sensory properties of the yogurt samples produced with high amounts of EPS-producing bacterial combinations were more appreciated by the panelists in terms of taste, odor, consistency and appearance.

Sensory values of the yogurt samples produced using the highest and lowest EPS producing strains and control strains are given in Table 5. The highest taste score was found in the yogurt produced with the Str56Lb94 combination $(5.00 \pm 0.00)$ and the lowest taste score was found in the yogurt produced with the Str132-Lb124 combination (3.50 \pm 0.00$)$. The highest odor score was found in the yogurts produced with the combinations of Str33-Lb94, Str56-Lb94 and Str164Lb103 $(4.50 \pm 0.00,4.50 \pm 0.00,4.50 \pm 0,00)$ and the lowest odor score was found in the yogurt produced with the Str132-Lb124 combination (3.75 \pm 0.25$)$. The highest consistency score was found in the yogurts produced with combinations of Str33-Lb94, Str56-Lb94 and Str164-Lb103 $(4.75 \pm 0.25,4.75 \pm 0.25,4.75 \pm 0.25)$ and the lowest consistency score was found in the yogurt produced with the Str132-Lb124 combination (3.25 \pm 0.25$)$. The highest appearance score was found in the yogurt produced with the combinations of Str33-

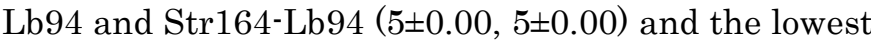
appearance score was found in the yogurt produced

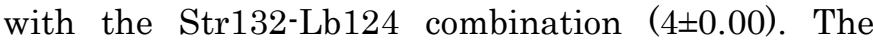
taste, smell, consistency and appearance scores of the yogurt produced by the control culture were $4.50 \pm 0.50$, $4.00 \pm 0.50,4.50 \pm 0.00$ and $4.50 \pm 0.00$. When the taste, odor, consistency, and appearance scores of the samples were examined, it was seen that the scores of the samples produced with the highest number of EPSproducing strains were higher than the scores of the samples produced with the lowest number of EPSproducing strains. In the statistical analyzes, it was determined that the effect of all strains on taste, consistency and appearance was significant $(p<0.05)$. In a previous study reported by Gürsoy et al., 2010, it was stated that sensory evaluation in yogurt (treatment D) ranged from 3.46 to 5.00 .

Table 6. Sensory analysis values of yogurts produced with different combinations

\begin{tabular}{|c|c|c|c|c|c|}
\hline Strain combinations & Taste & Odor & Consistency & Appearance & Total \\
\hline Str 33-Lb94 & $4.75 \pm 0.25$ & $4.50 \pm 0.00$ & $4.75 \pm 0.25$ & $5.00 \pm 0.00$ & $19.00 \pm 0.00$ \\
\hline Str33-Lb103 & $4.50 \pm 0.00$ & $4.00 \pm 0.00$ & $4.25 \pm 0.25$ & $4.50 \pm 0.00$ & $17.25 \pm 0.25$ \\
\hline Str56-Lb94 & $5.00 \pm 0.00$ & $4.50 \pm 0.00$ & $4.75 \pm 0.25$ & $4.75 \pm 0.25$ & $19.00 \pm 0.50$ \\
\hline Str56-Lb103 & $4.50 \pm 0.00$ & $4.00 \pm 0.50$ & $4.50 \pm 0.00$ & $4.50 \pm 0.00$ & $17.50 \pm 0.50$ \\
\hline Str164-Lb94 & $4.75 \pm 0.25$ & $4.25 \pm 0.25$ & $5.00 \pm 0.00$ & $5.00 \pm 0.00$ & $19.00 \pm 0.00$ \\
\hline Str164-Lb103 & $4.50 \pm 0.50$ & $4.50 \pm 0.00$ & $4.75 \pm 0.25$ & $4.75 \pm 0.25$ & $18.50 \pm 1.00$ \\
\hline Str166-Lb94 & $4.50 \pm 0.50$ & $4.25 \pm 0.50$ & $4.50 \pm 0.00$ & $4.50 \pm 0.00$ & $17.75 \pm 0.75$ \\
\hline Str166-Lb103 & $4.50 \pm 0.50$ & $4.00 \pm 0.50$ & $4.50 \pm 0.00$ & $4.50 \pm 0.00$ & $17.50 \pm 1.00$ \\
\hline Str132-Lb124 & $3.50 \pm 0.00$ & $3.75 \pm 0.25$ & $3.25 \pm 0.25$ & $4.00 \pm 0.00$ & $14.50 \pm 0.50$ \\
\hline Control & $4.50 \pm 0.50$ & $4.00 \pm 0.50$ & $4.50 \pm 0.00$ & $4.50 \pm 0.00$ & $17.50 \pm 1.00$ \\
\hline
\end{tabular}

\section{CONCLUSION}

As a result, the use of high amounts of EPS-producing cultures (BioStr33, BioStr56, BioStr 164, BioStr166, BioLb94, BioLb103) contributed positively to all the quality criteria examined for yogurt. By using these cultures instead of the use of additives, desired results can be obtained, regulation of the intestinal flora, lowering of cholesterol, antitumor and anti-ulcer activity of exopolysaccharides will result in preservation of human health. Also contributes to the economy.

\section{ACKNOWLEDGMENTS}

The authors would like to thank Kahramanmaraş Sütçü Imam University Scientific Research Council for financial support (Project No: 2015/1-75YLS) and the present study was derived from the MSc thesis entitled: Determination of The Potential Use of Exopolysaccharide-Producing Streptococcus salivarus ssp. thermophilus and Lactobacillus delbrueckii ssp. bulgaricus in Yogurt.

\section{REFERENCES}

Amatayakul T, Halmas A L, Sherkat F, Shah N P 
2005. Physical characteristics of yoghurt made using exopolysaccharide-producingstarter cultures and varying casein to whey protein rations. International Dairy Journal, 1:1-11.

Anonymus 1999. Yoğurt Standardı. TS 1330. Türk Standartları Enstitüsü, Ankara.

Bourlioux P, Pochart P 1988. Nutritional and health properties of yogurt. World Review of Nutrition Dietetics, 56:217-58.

Chabot S, Yu H L, Leseleuc L, Cloutier D, Calsteren M R, Lessard M, Roy D, Lacroix M, Oth D 2001. Exopolysaccharides from Lactobacillus rhamnosus RW-9595M stimulate TNF, IL-6 and IL-12 in human and mouse cultured immunocompetent cells, and IFN-g in mouse splenocytes. Lait, 81: 683-697.

Chandan R C, Shahani K M 1993. Yogurt. In: Hui YH, ed. Dairy Science and Technology Handbook. New York: VCH Publishers, Inc, 1-57.

Chaves A C, Fernandez M, Lerayer A L, Mierau I, Kleerebezem M, Hugenholtz J 2002. Metabolic engineering of acetaldehyde production by Streptococcus thermophilus. Applied and Environmental Microbiology, 68: 5656- 5662.

Cheng H F 2010. Volatile flavor compounds in yoghurt: A Review. Critical Reviews in Food Science and Nutrition, 50 (10): 938-944.

Dave R I, Shah N P 1997. Viability of yoghurt and probiotic bacteria in yoghurts made from commercial starter cultures. International Dairy Journal, 7: 31-41.

Duboc P, Mollet B 2001. Applications of exopolysaccharides in the dairy industry. International Dairy Journal, 11: 759-768.

Dubois M, Gilles K A, Hamilton J K, Rebers P A, Smith F 1956. Colorimetric method for determination of sugars and related substances. Analitical Chemistry, 28 (3): 350-352.

Garcia-Garibay M, Marshall V M E 1991. Polymer production by Lactobacillus delbrueckii ssp bulgaricus. Journal of Applied Bacteriology, 70; 325-328.

Gassem M A, Frak J F 1991. Physical properties of yoghurt made from milk tread with proteolytic enzymes. Journal of Dairy Science, 74: 1503.

German B, Schiffrin E J, Reniero R, Mollet B, Pfeifer A, Neeser J R 1999. The development of functional foods: lessons from the gut. Trends Biotechnology, 17: $492-499$.

Gezginc Y, Topcal F, Comertpay S, Akyol I 2015 Quantitative analysis of the lactic acid and acetaldehyde produced by Streptococcus thermophilus and Lactobacillus bulgaricus strains isolated from traditional Turkish yoghurts using HPLC. Journal of Dairy Science, 98: 1426-1434.

Güzel-Seydim Z B, Sezgin E, Seydin A 2005. Influences of exopolysaccharide producing cultures on the quality of plain set type yogurt. Food Control, 16:3, 205-209.

Han X, Yang Z, Jing X, Yu P, Zhang Y, Yi H, Zhang L 2016. Improvement of the texture of yogurt 10 by use of exopolysaccharide Producing Lactic Acid Bacteria. BioMed 11 Research International, 6 -12.

Hosono A, Lee J, Ametani A, Natsume M, Hirayama M, Adachi T, Kaminogawa S 1997. Characterization of a water-soluble polysaccharide fraction with immunopotentiating activity from Bifidobacterium adolescentis M101-4. Bioscience Biotechnology and Biochemistry, 61: 312-316.

Jolly L, Vincent S J F, Duboc P, Neeser J R 2002. Exploiting exopolysaccharides from lactic acid bacteria. Antony van Leeuwenhoek, 82: 367-374.

Kitazawa H, Harata T, Uemura J, Saito T, Kaneko T, Itoh T 1998. Phosphate group requirement for mitogenic activation of lymphocytes by an extracellular phosphopolysaccharide from Lactobacillus delbrueckii ssp. bulgaricus. International Journal Food Microbiology, 40: 169175.

Metin M, Öztürk G F 2002. Süt ve mamülleri analiz yöntemleri (Duyusal, fiziksel ve kimyasal analizler), Ege Meslek Yüksekokulu Basımevi, Bornova-İzmir, $439 \mathrm{~s}$.

Modler H W, Larmond M E, Lin C S, Froehlich D \& Emmons D B 1983. Physical and sensory properties of yoghurt stabilized with milk proteins. Journal of Dairy Science, 66: 422.

Nakajima H, Suzuki Y, Kaizu K, Hirota T 1992. Cholesterol lowering activity of ropy fermented milk. Journal Food Science, 57: 1327-1329.

Özoğul F, Taylor K D A, Quantick P C, Özoğul Y A 2000. Rapid HPLC-determination of ATP-related compounds and its application to herring stored under modified atmosphere. International Journal of Food Science \& Technology, 35: 549.

Routray W, Mishra H N 2011 Scientific and Technical Aspects of Yogurt Aroma and Taste:A Review. Comprehensive Review of Food Science, 10(4), 208210

Tamime AY, Robinson R K 2007 Yoghurt: Science and Technology 3rd ed. Woodhead Publishing Limited, Abington, England. 220.

Valerie M M, Rawson H L 1999. Effects of exopolysaccharide-producing strains of thermophilic lactic acid bacteria on the texture of stirred yoghurt. International Journal of Food Science and Techonology, 34: 137-143.

Welman A D, Maddox I S 2003. Exopolysaccharides from lactic acid bacteria: perspectives and challenges. Trends in Biotechnology, 21:6, 269-274.

Yildiz,F.2010. Development and Manufacture of yoğurt and Functional Dairy Products. Taylor and Francis Group, United States. 454p. 